\title{
Association between mineralization of third molars and chronological age in a Brazilian sample
}

\author{
Associação entre mineralização dos terceiros molares e idade \\ cronológica em uma amostra brasileira
}

\begin{abstract}
Purpose: To evaluate the association between chronological age and mineralization of third molar teeth in a sample from the Northeast region of Brazil.

Methods: A sample of 173 digitized panoramic radiographs were selected from a total of 2,442 panoramic radiographs obtained over a period of 6 months at a private Dental Radiology service, in the city of João Pessoa, PB, Brazil. The patients were aged from 5.5 to 21 years, and a calibrated examiner made the evaluation using the classification proposed by Demiriian. Data were analyzed by using an adjusted multiple linear regression model considering age as a response variable. The level of significance adopted was 0.05 .

Results: Gender and stage of calcification were significantly correlated associated with age. There was no effect of gender on mineralization of the teeth. Between the two consecutive stages of calcification of third molar teeth, the mean increase in age varied by 16 months.

Conclusion: The results suggest that the development of the third molar teeth is similar in both sexes. Calcification of third molars may be an auxiliary tool in the study of chronological age.
\end{abstract}

Key words: Panoramic radiography; age determination by teeth; third molar; tooth calcification

\section{Resumo}

Objetivo: O objetivo deste estudo foi avaliar a associação entre idade cronológica e mineralização dentes terceiros molares em uma amostra brasileira de João Pessoa, PB, Brazil.

Metodologia: De um total de 2442 radiografias panorâmicas digitalizadas obtidas num período de seis meses, em serviço privado de Radiologia Odontológica, na cidade de João Pessoa, PB, Brazil, foram selecionadas 173. Os pacientes tinham entre 5,5 a 21 anos de idade. Um avaliador calibrado fez as avaliações utilizando a classificação proposta por Demirjian. Para a análise, ajustou-se um modelo de regressão linear múltipla, considerando a idade como variável resposta. O nível de significância adotado foi de 0,05.

Resultados: Tanto o sexo quanto o estágio de calcificação estiveram significativamente associados com as idades dos pacientes. Não houve diferenças significativas na mineralização dos dentes entre os sexos. Entre dois estágios consecutivos, o aumento médio da idade variou 16 meses.

Conclusão: Concluiu-se que há semelhança do desenvolvimento entre os dentes terceiros molares em ambos os sexos. A calcificação dos terceiros molares pode ser uma ferramenta auxiliar no estudo da idade cronológica.

Palavras-chave: Radiografia panorâmica; determinação da idade pelos dentes; terceiros molares; calcificação dental

\author{
Amanda Maria Medeiros de Araújo a \\ Maria Luiza dos Anjos Pontual b \\ Kalianna Pereira de França ${ }^{b}$ \\ Ricardo Villar Beltrão b \\ Andréa dos Anjos Pontual c
}

\begin{abstract}
a Academic Unit of Biological Sciences, School of Dentistry, Federal University of Campina Grande - UFCG, Patos, PB, Brazil

b Department of Clinic and Social Dentistry, School of Dentistry, Federal University of Paraíba-UFPB, João Pessoa, PB, Brazil

c Department of Oral Diagnosis, School of Dentistry, Pernambuco University-UPE, Camaragibe, PE, Brazil
\end{abstract}

\author{
Correspondence: \\ Amanda Maria Medeiros de Araújo \\ Universidade Federal de Campina Grande \\ Centro de Saúde e Tecnologia Rural \\ Unidade Acadêmica de Ciências Biológicas \\ Curso de Odontologia \\ Avenida Universitária - Bairro Santa Cecília \\ Caixa Postal 64 \\ Patos, PB - Brasi \\ 58700-970 \\ E-mail: araujo.amm@gmail.com
}

Received: March 3, 2010

Accepted: September 29, 2010

Conflict of Interest Statement: The authors state that there are no financial and personal conflicts of interest that could have inappropriately influenced their work.

Copyright: (C) 2010 Araúio et al.; licensee EDIPUCRS. This is an Open Access article distributed under the terms of the Creative Commons AttributionNoncommercial-No Derivative Works 3.0 Unported License. 


\section{Introduction}

As the biological or chronological age of a human being does not correspond directly to the real stage of body development, other parameters have been investigated for this purpose, such as dental, bone or skeletal age, mental age, secondary sexual characteristics, height and weight (1). Information about normal growth and development are objective records of the maturational status of the body at a certain time (2). These questions are of great importance in forensic dentistry $(3,4)$, in orthopedics and orthodontics, and in the research of the circumpuberal growth spurt (5). For example, forensic dentistry employs specific methods to estimate the chronological age yielding results that more accurate than other medical estimates, since the dental elements are more susceptible to the nutritional, hormonal and pathological alterations in children $(3,6,7)$.

The appearance of ossification centers and tooth formation may vary according to ethnic and socioeconomic factors and due to considerable genetic variations (2). The findings by Carvalho et al. (2) and Saliba et al. (4) showed that Brazilian female subjects presented earlier development of permanent teeth than male subjects, whereas Sisman et al. (8) found the opposite results. Olze et al. found significant differences in the degree of mineralization of the third molars between Germans and Japanese (9) and between Germans and subjects from South Africa (10), and they concluded that the degree of mineralization could be used to determine the age of unidentified persons and skeletons.

Some European countries have experienced an increasing movement of migration over the last years due to the globalized economy and armed conflicts. Some persons do not know their age or deny their true age, and this problem has required studies on investigating the chronological age of these individuals by the stages of calcification of the third molar teeth (9). In Brazil there is great diversity of ethnic influences in the population, and the degree of dental calcification of the third molars could be an auxiliary tool to estimate chronological age (12).

Previous studies investigated dental calcification and chronological age in Brazil $(1,2,12-16)$, but no data are available from the Northeast region where the population has a history of ethnic mixture among native Indians, European and African groups for centuries. Therefore, the aim of this study was to evaluate the association of chronological age and degree of calcification of the third molars in a sample from the Northeast region of Brazil, using panoramic radiographic images.

\section{Methodology}

This study was approved by the Centre of Health Sciences Ethics Committee of the Federal University of Paraíba, in João Pessoa, PB, Brazil. A total of 2,442 digitized panoramic images were obtained over a period of 6 months at a private dental radiology service in the city of João Pessoa, PB, Brazil, and screened according the following inclusion criteria: subjects born in the state of Paraiba; age range between 5.5 and 21 years old; no restriction of ethnicity or gender. The exclusion criteria were: history of extraction of permanent tooth; history of trauma to the bones of the face; presence of any dental developmental disorders and history of systemic diseases. According to the elegibility criteria, 173 panoramic radiographic images were selected to compose the study sample.

All the panoramic radiographs were taken with the X-ray equipment Rothograph Plus ${ }^{\circledR}$ (Dabi Atlante Ltda., Ribeirão Preto, SP, Brazil) operating at $13 \mathrm{~s}, 10 \mathrm{~mA}$ and a $\mathrm{kV}$ according to the patient. T-mat, size $12.7 \times 30.5 \mathrm{~cm}$ films (EastmanKodak Co., Rochester, NY, USA) were used. After exposure, the films were processed manually by the temperature/time method using Kodak solutions (Eastman Kodak, Rochester, USA).

The radiographs were digitized with a resolution of 300 dpi, in tiff format using a scanner (Hewlett-Packard, USA) with a transparency screen. All the images were exported and randomly evaluated in a dark room by a trained radiologist using the Windows ${ }^{\circledR}$ Image and Fax Viewer. The modified classification proposed by Demirjian et al. (17) was used (Fig. 1) to analyze the degree of calcification. Stage 0 , defined as the crypt stage without presenting any sign of calcification of the tooth germ, was added to the Demirjian classification. A maximum of 10 images per day were evaluated, and the stage of development recorded on a standardized spreadsheet.

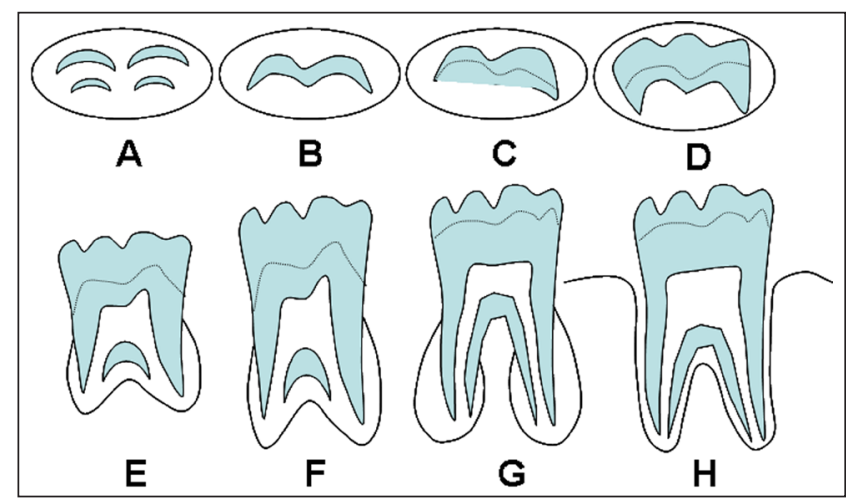

Fig. 1. Classification of the degree of mineralization of molar teeth according to Demiriian et al. (7).

To evaluate the relationship between age, Demirjian stage of calcification, gender and type of tooth, an adjusted multiple linear regression model was used, considering age as a variable response. In all the tests, the level of significance of 0.05 was adopted. Statistical analysis was performed using Stata 9.2 and Minitab 15 softwares.

\section{Results}

Of the 173 images, $52 \%$ were from male and $48 \%$ from female subjects. Table 1 shows the mean age for each third 
molar tooth in the eight Demirjian stages of calcification. The Dermirjian stage of calcification was found to be significantly associated with age, presenting a significant mean increase of 15.9 months between two consecutive stages (Fig. 2 and Table 2). With regard to the type of third molar tooth, there was no significant difference between the mean age of each third molar tooth for all stages of calcification. Therefore, the same equation could be established for all third molars to determine the chronological age:

$$
\text { Age }=98.1+15.9 \text { Demirjian stage }
$$

Table 1. Means of age in Stage 0 and in the Demiriian stages of calcification in each third molar tooth (tooth \#18, 28, 38 and 48).

\begin{tabular}{ccccc}
\hline \multirow{2}{*}{ Stage of development Third molar tooth } \\
\cline { 2 - 5 } & 18 & 28 & 38 & 48 \\
\hline O & 111.9 & 106.9 & 118.8 & 102.3 \\
A & 110.3 & 106.3 & 109.1 & 110.3 \\
B & 117.8 & 127.0 & 122.1 & 130.3 \\
C & 140.9 & 139.0 & 149.6 & 143.1 \\
D & 161.3 & 155.7 & 160.7 & 156.0 \\
E & 183.9 & 183.5 & 185.7 & 183.2 \\
F & 214.3 & 193.5 & 197.8 & 205.5 \\
G & 207.6 & 209.1 & 202.9 & 198.5 \\
H & 223.7 & 227.7 & 225.5 & 231.3 \\
\hline
\end{tabular}

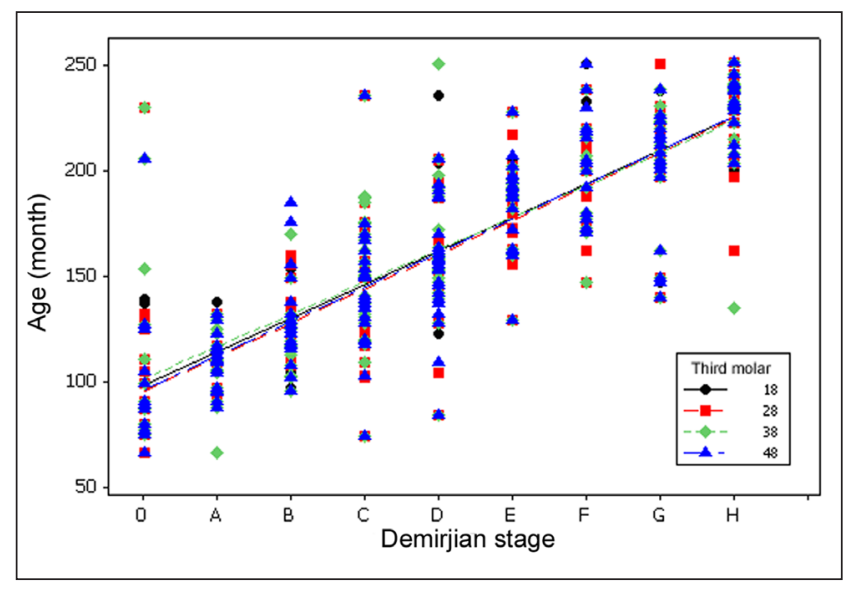

Fig. 2. Relationship between chronological age in months and the Demirjian stage between each third molar tooth.

Table 2. Results of the linear regression models adjusted to third molars in relation to the difference between the mean ages in the Demirjian stages of calcification.

\begin{tabular}{lcccc}
\hline Variable & $\begin{array}{c}\text { Coefficient } \\
\text { B }\end{array}$ & $\begin{array}{c}\text { Robust } \\
\text { standard } \\
\text { error }\end{array}$ & $\mathbf{t}$ & $\mathbf{P}$ \\
\hline Constant & 98.1 & 3.82 & 25.64 & $<0.001$ \\
Demirian stage & 15.9 & 0.77 & 20.10 & $<0.001$ \\
\hline
\end{tabular}

$R^{2}=67 \%$.
When evaluating the influence of sex on the development of third molar teeth (Fig. 3 and Table 3), there was no significant difference in the calcifications stage of third molar teeth between male and female subjects. The development of third molar teeth on the right and left sides was similar in the majority of the Demirjian stages.

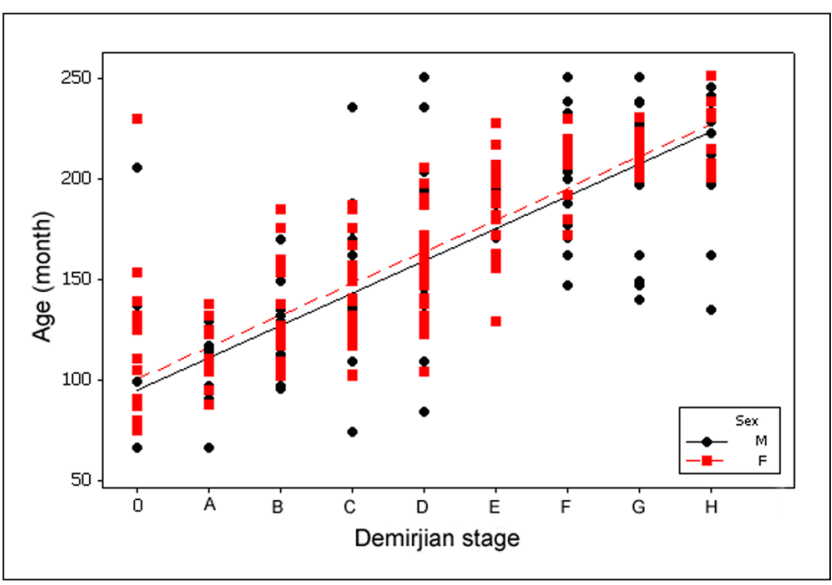

Fig. 3. Relationship between chronological age in months and the Demirjian stage as a function of gender.

Table 3. Results of the linear regression models adjusted to third molars in relation to the influence of sex and the presence of difference between the mean ages in the Demirian stages of calcification in third molar teeth.

\begin{tabular}{lcccc}
\hline $\begin{array}{c}\text { Explanatory } \\
\text { variable }\end{array}$ & $\begin{array}{c}\text { Coefficient } \\
\text { B }\end{array}$ & $\begin{array}{c}\text { Robust } \\
\text { standard } \\
\text { error }\end{array}$ & $\boldsymbol{t}$ & $\boldsymbol{P}$ \\
\hline Constant & 91.3 & 6.44 & 14.19 & $<0.001$ \\
Demiriian stage & 16.0 & 0.77 & 20.69 & $<0.001$ \\
Sex & 4.3 & 3.66 & 1.18 & 0.238 \\
\hline
\end{tabular}

$R^{2}=67 \%$.

\section{Discussion}

Methods based on the stages of tooth formation are shown to be more accurate for estimating biological age than those based on other developmental indicators $(1,12,14)$. When dental radiographs can be used, the method of choice for estimating age in young individuals is the analysis of the different stages of mineralization of the teeth (3). The panoramic radiograph is the preferred instrument to assess the stages of dental calcification $(1,8,12,19)$, enabling a broad view of the tooth and facial bones (12). The present study used the classification of the stages of mineralization proposed by Demirjian (17) often used worldwide (5-11,18-20). Nevertheless, the Demirjian classification does not cover the crypt stage of tooth development. Thus, the present study used a modification of the original Demirjian classification system adding a Stage 0 to indicate the crypt stage of tooth development. 
This study found no significant difference in the mean ages of the mineralization stages as previously shown in other populations $(14,20)$. However, other studies found earlier development of teeth for the female gender $(1,2,4,10,13)$ and others for the male gender $(6,8,19)$. The results of the present study suggest that the absolute velocity in the increment of mineralization of the teeth is equal between the sexes, and the small difference in dental growth of patients of the female sex is probably due to the smaller size of the tooth, which was previously discussed by Ferreira Junior et al. (14). Considering possible differences in mineralization of third molars in relation to the mouth side and dental arch, no significant differences were found, similarly to previous reports $(4,10,19,20)$. The development of third molars in terms of presence, formation, mineralization and position is unpredictable and has great variation in the population (12, 13). Nevertheless, it seems to be possible to use the dental age of third molars as measured by the Demirjian classification (17) to determine the age category of subjects in complex populations with many ethnic groups $(5,7-10,19,20)$.

A variety of studies have been conducted to determine the stages of mineralization of third molars and their relationship with chronological and bone age by ethnic group and sex $(4,5,7-10,12,14,19,20)$. The sample in the present study had a mean age of 9 years old for stage $\mathrm{A}$, but other studies reported stage A values of 12 years old for Turkish subjects (8) and 6 years old for Spaniards (7). For stage H, the present study found a mean age of 19 years old, while in Germans and the Japanese (9), Africans (10) and Turkish subjects (8), the mean age for stage $\mathrm{H}$ was higher than 21 years old. It is important to study the mean age for the degrees of calcification of third molar teeth in the different regions of Brazil, since the results were different in at least one of the teeth studied in comparison with the literature.

Calcification tables to estimate chronological age should be used as an auxiliary tool to investigate human characteristics within the ethical standards and professional good practice. Since physical and developmental characteristics vary greatly among the population groups in many regions of Brazil and the world (4), it is important to adopt a reliable and validated tool to study the chronological age by the mineralization of teeth in different populations.

\section{Conclusions}

Within the limitations of the present study, it can be concluded that:

- Third molars present similar development regarding sex, type of molar and dental arch;

- It is possible to estimate the age of a patient from 5.5 to 21 years old according to the stages of calcification of the third molar teeth.

\section{References}

1. Moraes MEL, Médice Filho E, Moraes LC. Surto de crescimento puberal. Relação entre mineralização dentária, idade cronológica, idade dentária e idade óssea - Método Radiográfico. Rev. Odontol. UNESP 1998;27:111-29.

2. Carvalho AAF, Carvalho A, Santos-Pinto MC. Estudo radiográfico do desenvolvimento da dentição permanente de crianças brasileiras com idade cronológica variando entre 84 e 131 meses. Rev. Odontol. UNESP 1990;19:31-9.

3. Gonçalves ACS, Antunes JLF. Estimativa da idade em crianças baseada nos estágios de mineralização dos dentes permanentes, com finalidade Odontolegal. Rev. Odont. Socied 1999;1:55-62.

4. Saliba CA, Daruge E, Gonçalves R, Saliba TA. Estimativa da idade pela mineralização dos dentes, através de radiografias panorâmicas. ROBRAC 1997;6:14-6.

5. Uysal T, Sari Z, Ramoglu SI, Basciftci FA. Relation between dental and skeletal maturity in Turkish subjects. Angle Orthodont 2004;74:657-64.

6. Bai Y, Mao J, Zhu S, Wei W. Third molar development in relation to chronologic age in young adults of central China. J Huazhong Univ Sci Technol Med Sci 2008;28:487-90.

7. Bolãnos MV, Moussa H, Manrique MC, Bolãnos MJ. Radiographic evaluation of third molar development in spanish children and young people. Forensic Sci Int 2003;133:212-9.

8. Sisman Y, Uysal T, Yagmur F, Ramoglu SI. Third-molar development in relation to chronologic age in Turkish children and young adults. Angle Orthodont 2007;77:1040-5

9. Olze A, Reisinger W, Geserick G, Schmeling A. Age estimation of unaccompanied minors. Part II. Dental aspects. Forensic Sci Int 2006;159:65-7.

10. Olze A, Van Niekerk P, Schmidt S, Wernecke KD, Rösing FW, Geserick $G$, et al. Studies on the progress of third-molar mineralization in a Black African population. Forensic Sci Int 2006:57:209-17.
11. Olze A, Taniguchi M, Schmeling A, Zhu BL, Yamada Y, Maeda $\mathrm{H}$, et al. Comparative study on the chronology of third molar mineralization in a Japanese and German population. Legal Med 2003;5:256-60

12. Cordeiro RCL, Gonçalves MA, Pinto LAMS, Estigarribia CCG. Estágios de calcificação e erupção dos dentes permanentes de crianças da zona rural de Araraquara/SP. JBO 2000;25:47-56.

13. Cordeiro RCL, Santos-Pinto LAM, Gonçalves MA, Mendes AJD. Ełapas da formação e mineralização do terceiro molar em crianças. Estudo radiográfico. Rev. Odontol. UNESP 1999;28:401-14.

14. Ferreira Junior ER, Santos-Pinto LAM, Santos-Pinto R. Estágio de mineralização dental: 1. Análise comparativa entre sexos. Rev. Odontol. UNESP 1993;23:303-13.

15. Mazzieiro ET, Eło LF. Avaliação da correlação entre os estágios de mineralização dos dentes inferiores e a idade esquelética observados sob o gráfico de crescimento puberal. Rev. Dent. Press Ortodon. Ortop. Facial 2005; 10:75-86.

16. Nicodemo RA, Moraes LC, Médici Filho E. Tabela cronológica da mineralização dos dentes permanentes, entre brasileiros. Rev. Fac. Odontol. São José dos Campos 1974;3:55-6.

17. Demirian A, Goldstein H, Tanner JM. A new system of dental age assessment. Hum Biol 1973;45:211-27.

18. De Salvia A, Calzetta C, Orrico M, De Leo D. Third mandibular molar radiological development as na indicator of chronological age in a European population. Forensic Sci Int 2004;146:S9-S12.

19. Meinl A, Tangl S, Huber C, Maurer B, Watzek G. The chronology of third molar mineralization in the Austrian population - a contribution to forensic age estimation. Forensic Sci Int 2007;169:161-7.

20. Orhan K, Ozer L, Orhan Al, Dogan S, Paksoy CS. Radiographic evaluation of third molar development in relation to chronological age among Turkish chidren and youth. Forensic Sci Int 2007;1 65:46-51. 